Анализируя энергетические кривые обнаружено, что молекула муравьиной и молочной кислоты не адсорбируется на поверхности трубки, что обосновывается отсутствием минимума на энергетических кривых, иллюстрирующего факт образования химической связи между молекулой кислоты и атомом трубки. Таким образом можно использовать УНТ в качестве защитной среды от воздействия кислот на зубную эмаль. Поэтому необходимо выяснить как взаимодействует гидроксиапатит и УНТ. Для взаимодействия был предложен следующий механизм: УНТ и элементарная ячейка ГА располагались относительно друг друга на расстоянии $2 \AA$. Проведенная полная оптимизация геометрии в этом состоянии показала, что УНТ и ГА объединились в адсорбционный комплекс. Таким образом можно предложить использовать УНТ для покрытия зубной эмали для защиты от воздействия вредных кислот.

1. В.Н. Трезубов, М.З. Штейнгарт, Л.М. Мишнев Ортопедическая стоматология. Прикладное материаловедение: Учебник для медицинских вузов, СПб.: Специальная литература (1999).

\title{
MODELING OF CERIUM OXIDE NANOPARTICLES PHARMACOKINETICS
}

\author{
Kasyanova V.V. ${ }^{1}$, Bazhukova I.N. ${ }^{1}$ \\ 1) Ural Federal University, Yekaterinburg, Russia \\ E-mail: ValentinaKasianova@yandex.ru
}

Cerium oxide nanoparticles pharmacokinetics model was developed. The biodistribution of nanoparticles in various organs and tissues of the body after intravenous injection was evaluated. The parameters that have the greatest influence on the nanoparticles distribution were determined.

A comprehensive study of nanoparticles properties has shown the great potential of their use in medicine. Cerium oxide nanoparticles are one of the promising materials in this field due to their ability to interact with reactive oxygen species (ROS) and perform the functions of enzymes. It was shown that these nanoparticles are able to protect cells from ROS and thereby prevent diseases associated with oxidative stress [1]. However, the use of these nanomaterials in medicine requires date about their toxicity and distribution in the body after injecting. A physiologically based pharmacokinetic modeling (PBPK) is a convenient tool for solving this problem. Simulation data provide important information on the absorption, distribution, metabolism, and excretion of nanoparticles. So, this study is devoted to modeling the systemic distribution of intravenously injected cerium oxide nanoparticles.

The PBPK model of nanoparticles was implemented using Matlab SimBiology ${ }^{\circledR}$ R2018b software. The model consists of several compartments: lungs, spleen, liver, 
kidneys, heart, brain, gastrointestinal tract, and other organs. Like biological systems, all compartments were interconnected by a circulating blood system, which was modeled by two additional compartments - arterial and venous blood. All compartments except blood contain three subcompartments: capillary blood, tissue, and phagocytes. To describe the nanoparticles concentration changes in each compartment a set of linked ordinary differential equations was used. Both anatomical and physiological parameters of biological object and nanoparticles parameters were used as model parameters [2].

The model was optimized using published experimental data on the cerium nanoparticles biodistribution in various tissues of rats after intravenous injection [2,3]. During the simulation, physiological parameters were fixed, and the nanoparticles parameters were optimized by fitting the simulation results to the available experimental data. In order to simplify the model, the parameters had the same values for most organs.

The sensitivity analysis of the model was carried out to determine the parameters that have the greatest effect on the nanoparticles biokinetics. It was found that the pharmacokinetics of nanoparticles is more dependent on the distribution coefficient between tissue and blood, the permeability coefficient between blood and tissue, and the maximum rate of phagocyte uptake. Thus, it was shown that both the anatomical and physiological parameters of biological organism, as well as the physicochemical parameters of nanoparticles, influence the biodistribution of nanoparticles.

The constructed PBPK model can be used to predict the distribution of cerium dioxide nanoparticles in various organs after their intravenous injection. Varying the model parameters makes it possible to evaluate the change in nanoparticles biokinetics under different conditions.

1. Wang G., Zhang J., He X. et al., Chinese Journal of Chemistry, 35, 1 - 10 (2017).

2. Carlander U., Moto T., Desalegn A. et al., International Journal of Nanomedicine, 13, $2631-2646$ (2018).

3. Li D., Morishita M., Wagner J. et al., Particle and Fibre Toxicology, 13 (2016). 